\title{
Survei Tingkat Kebugaran Jasmani Siswa SMP
}

\author{
Achmad Arifandy*, Eko Hariyanto, Usman Wahyudi \\ Universitas Negeri Malang, Jl. Semarang No. 5 Malang, Jawa Timur, Indonesia \\ *Penulis korespondensi, Surel: arifandi950@gmail.com
}

Paper received: 3-5-2021; revised: 24-5-2021; accepted: 28-5-2021

\begin{abstract}
Abstrak
Tujuan penelitian ini untuk mengetahui tingkat kebugaran jasmani siswa SMP Insan Terpadu Pakis Kabupaten Malang dalam kegiatan olahraga, Rancangan penelitian yang digunakan dalam penelitian ini adalah survei bentuk deskriptif. Subjek dalam penelitian ini adalah siswa SMP Insan Terpadu Pakis Kabupaten Malang yang mengikuti semua kegiatan olahraga di SMP Insan Terpadu Pakis Kabupaten Malang yang berjumlah 64 siswa. Metode dalam pengumpulan data ini menggunakan Tes Kebugaran Jasmani Indonesia (TKJI). Teknik pengukuran bentuk tes yaitu, data yang terkumpul dianalisis menggunakan statistika deskriptif kuantitatif. Hasil analisis data mengggunakan teknik analisis data statistika deskriptif kuantitatif diperoleh tingkat kebugaran jasmani siswa SMP Insan Terpadu Pakis Kabupaten Malang termasuk dalam kategori baik 45,31 persen, dan pada kategori sedang 54,69 persen. Kesimpulan yang diperoleh dari survei yang dilakukan pada tingkat kebugaran jasmani siswa dengan tes TKJI. Siswa SMP Insan Terpadu Pakis Kabupaten Malang menunjukkan bahwa tingkat kebugaran jasmaninya cenderung dalam kategori sedang.
\end{abstract}

Kata kunci: kebugaran jasmani; tes kebugaran jasmani indonesia

\section{Pendahuluan}

Pendidikan jasmani olahraga dan kesehatan yang diajarkan di sekolah memiliki peranan sangat penting, yaitu memberikan kesempatan kepada siswa didik untuk terlibat langsung dalam berbagai pengalaman belajar melalui aktivitas jasmani, olahraga dan kesehatan yang terpilih dan dilakukan secara sistematis. Pembekalan pengalaman belajar itu diarahkan untuk membina pertumbuhan fisik dan pengembangan psikis yang lebih baik, sekaligus membentuk pola hidup sehat dan bugar sepanjang hayat. Widijoto (2009) menyatakan bahwa pendidikan jasmani adalah aktivitas psikomotorik yang dilaksanakan atas dasar pengetahuan (kognitif), dan pada saat melaksanakannya akan terjadi perilaku pribadi yang terkait dengan sikap/afektif (seperti kedisiplinan, kejujuran, percaya diri, ketangguhan) serta perilaku sosial (seperti kerjasama, saling menolong), atau pendidikan jasmani dapat diartikan sebagai suatu proses pembelajaran melalui aktivitas jasmani yang didesain secara sistematik untuk meningkatkan kebugaran jasmani, mengembangkan keterampilan motorik, yang akan baik pelaksanaannya apabila didukung dengan pengetahuan tentang cara melakukannya, perilaku hidup sehat, aktif, akan mengembangkan sikap jujur, disiplin, percaya diri, tangguh, pengendalian emosi serta kerjasama, saling menolong. Lumpkin(2010)berpendapat bahwa pendidikan jasmani didefinisikan sebagai proses hingga seorang individu memperoleh fisik yang optimal,mental, sosial, dan kebugaran melalui aktivitas gerak.

Kurniawan (2017) Pendidikan jasmani dan kesehatan pada hakikatnya adalah proses pendidikan yang memanfaatkan aktivitas fisik dan kesehatan untuk menghasilkan perubahan holistik dalam kualitas individu,baik dalam hal fisik,mental,serta emosional. Olahraga merupakan sesuatu yang tidak asing lagi ditelinga kita. Banyak orang-orang yang gemar melakukan olahraga, baik itu dari anak-anak hingga lanjut usia. Anak-anak melakukan olahraga sebagai suatu kesenangan dan sebagai suatu sarana untuk berprestasi, salah satunya 
dengan mengikuti pembelajaran pendidikan jasmani yang ada di sekolah. Olahraga merupakan merupakan budaya manusia, artinya tidak dapat disebut ada kegiatan olahraga apabila tidak ada faktor manusia yang berperan secara ragawi atau pribadi melakukan aktivitas olahraga itu (Giriwijoyo dan Sidik, 2013).Kebugaran jasmani yang lebih tinggi dapat meningkatkan penampilan para olahragawan dan mengurangi kemungkinan terjadinya cedera. Pengalaman yang ada menunjukkan bahwa orang yang teratur melakukan aktifitas olahraga akan mendapatkan suatu hal yang berharga, hal tersebut adalah kesehatan.Oleh karena itu untuk mendapatkan kebugaran jasmani, manusia dianjurkan melakukan gerak dan berolahraga tanpa adanya paksaan dari orang lain.

Menurut Mulyaningsih (2010) kebugaran jasmani artinya kemampuan melaksanakan tugas sehari-hari dengan kondisi tubuh tetap bugar. Kebugaran jasmani merupakan bagian dari total fitness. Di dalam total fitness terdapat beberapa komponen, yaitu: Anatomical fitness, physiologycal fitness dan psychological fitness. Menurut Nurhasan, dkk (2005) ada 2 komponen yang berkaitan dengan kebugaran jasmani, meliputi: kebugaran jasmani yang berkaitan dengan kesehatan yaitu setiap orang perlu memiliki komponen kebugaran jasmani yang berhubungan dengan kesehatan dan mampu melakukan aktivitas sehari-hari dengan tenaga yang dibutuhkan. Komponen-komponen tersebut meliputi: kekuatan (strengh), Kelentukan (flleksibility), Komposisi tubuh (body composition), Daya tahan (endurence). Kemudian komponen kebugaran jasmani yang berhubungan dengan keterampilan yaitu komponen yang berhubungan dengan keterampilan gerak penting untuk menunjang aktivitas sehari-hari, khususnya dalam aktifitas olahraga, beberapa komponen tersebut meliputi: Kecepatan (speed), Kelincahan (agibility), Daya ledak(power), Keseimbangan (balance), Koordinasi (coordination), Kecepatan reaksi (reaction speed). Menurut Nurhasan,dkk (2005) kebugaran jasmani pada umumnya dipengaruhi oleh 2 faktor utama yaitu faktor internal dan faktor eksternal. Yang dimaksud dengan faktor internal adalah sesuatu yang sudah ada didalam tubuh seseorang yang bersifat menetap, misalnya faktor genetik, umur, jenis kelamin.Sedangkan faktor eksternal diantaranya adalah aktivitas fisik, status gizi, status kesehatan, kadar hemoglobin, kecukupan istirahat dan kebiasaan merokok. Kebugaran jasmani juga sangat berpengaruh dengan kegiatan siswa yang di lakukan di sekolah.

Dalam olahraga diperlukan kebugaran jasmani yang baik, karena kebugaran yang baik mempengaruhi kegiatan yang dilakukan oleh seseorang. Tubuh yang sehat dan bugar adalah harapan bagi semua orang, karena untuk bisa menjalankan aktivitas yang dihadapi agar dapat menghasilkan sesuatu yang produktif. Sebagai makhluk hidup yang diberikan berbagai organ tubuh lengkap harus menjaga agar organ-organ tersebut bergerak sebagaimana mestinya supaya menjadi makhluk hidup yang sehat. Mengingat kebugaran jasmani mempunyai peranan yang sangat penting dalam kondisi latihan dan pertandingan, maka setiap olahragawan termasuk siswa sebaiknya memperhatikan unsur kebugaran jasmani sejak awal. Pelatih Atau guru olahraga harus mengetahui tingkat kebugaran jasmani peserta didiknya, karena hal tersebut akan berdampak terhadap prestasi. Untuk dapat merancang pembelajaran yang bertujuan meningkatkan kebugaran jasmani siswa, guru dan pelatih memerlukan informasi awal untuk tingkat kebugaran jasmani siswa sebagai pijakan dalam melakukan pembelajaran.

Dari hasil observasi yang dilakukan oleh peneliti yang melakukan penelitian di SMP Insan Terpadu Kabupaten Malang pada tanggal 12-14 September 2019 peneliti melakukan observasi awal dengan melakukan pengamatan aktivitas siswa selama disekolah. Banyak siswa 
yang pergi ke sekolah dengan berjalan kaki dikarenakan sebagian besar siswa yang bersekolah di SMP Insan Terpadu merupakan santri dari Pondok Pesantren ASY-SYADZILI, ada beberapa siswa yang diantar oleh orang tuanya.berdasarkan wawancara yang dilakukan dengan guru olahraga, guru olahraga tersebut menuturkan bahwa banyak siswa yang kurang aktif pada saat kegiatan pembelajaran pendidikan jasmani dan kesehatan berlangsung.

Dari hasil penelitian yang telah dilakukan oleh Puspitasari (2017), diperoleh nilai maksimal sebesar 107,66 dan nilai minimal sebesar 7,70. Mean sebesar 51,53. Median sebesar 48,88. Modus sebesar 43,78. Standar deviasi sebesar 18,85 dan varian sebesar 355,32. Sedangkan dari hasil keseluruhan tingkat kebugaran jasmani siswa SMP Negeri 2 Sendang, Kabupaten Tulungagung menunjukkan kategori baik 20\%, cukup 69\% dan kurang 11\%. Sehingga dari data tersebut tingkat kebugaran jasmani siswa SMP Negeri 2 Sendang, Kabupaten Tulungagung termasuk dalam kategori cukup.

Berdasarkan hasil penelitian dari Ginting (2012), uji analisis dan pembahasan hasil penelitian maka dapat disimpulkan sebagai berikut: Siswa SMP Negeri 1 Kabanjahe Tahun Ajaran 2011/2012 memiliki tingkat kebugaran jasmani kurang. 2) Siswa SMP Negeri 1 Kabanjahe secara umum memiliki Indeks Massa Tubuh pada kategori normal, yaitu pada -2SD sampai 2SD. 3) Siswa obesitas memiliki tingkat kebugaran jasmani yang lebih rendah dibandingkan dengan siswa kurus, normal, dan gemuk. 4) Terdapat korelasi negatif antara Indeks Massa Tubuh dengan tingkat kebugaran jasmani pada siswa SMP Negeri 1 Kabanjahe tahun ajaran 2011/2012. 5) Semakin tinggi Indeks Massa Tubuh, semakin rendah tingkat kebugaran jasmani. 6) Nilai Indeks Massa Tubuh harus diimbangi dengan aktivitas fisik yang teratur.

Berdasarkan latar belakang masalah yang telah dipaparkan, maka peneliti melakukan penelitian yang berjudul "Survei Tingkat Kebugaran Jasmani Siswa SMP Insan Terpadu Pakis Kabupaten Malang".

Pendidikan Jasmani, yang dalam kurikulum disebut secara paralel dengan istilah lain menjadi Pendidikan Jasmani, Olahraga dan Kesehatan, merupakan salah satu mata pelajaran yang disajikan di sekolah, mulai dari SD, SMP sampai dengan SMA. Morgan (2008:197) menyatakan bahwa manfaat pendidikan jasmani telah diakui secara luas sebagai sarana gerak utama bagi peserta didik untuk mengembangkan pengetahuan dan keterampilan fisik secara aktif. Melalui program pendidikan jasmani olahraga dan kesehatan peserta didik dibentuk dan diajarkan untuk hidup sehat dan mempunyai kebugaran yang baik, sehingga nantinya mampu bekerja secara optimal khususnya dalam perkembangan ilmu pengetahuan yang begitu pesat karena hanya orang yang memiliki kebugaran baiklah yang akan lebih produktif dibandingkan orang yang memiliki tingkat kebugaran yang rendah.Menurut Mardiana (2014) pendidikan jasmani dan olahraga mempunyai perbedaan dan persamaan. Berdasarkan ruang lingkup kegiatannya maka pendidikan jasmani lebih luas dari olahraga (sport), games, bermain (play) dan segala aktivitas untuk mengembangkan kualitas manusia melalui gerak. Dalam pendidikan jasmani (physical education) mempunyai unsur bermain dan olahraga, tetapi tidak sematamata hanya bermain dan olahraga saja melainkan kombinasinya keduanya. Dengan nama pendidikan jasmani aktivitas fisik berorientasi pada tujuan pendidikan, yaitu mencoba melakukan kegiatan mendidik melalui aktivitas fisik. Akan tetapi pada kegiatan bermain dan olahraga tidak berorientasi pada tujuan pendidikan. 
Dari berbagai pendapat tentang pengertian pendidikan jasmani, dapat disimpulkan bahwa pendidikan jasmani olahraga dan kesehatan merupakan bagian dari sistem pendidikan di Indonesia, maka dari itu guru memiliki peranan penting dalam membentuk karakter anak, selain itu guru juga harus memang berkompeten dalam bidangnya hal ini berkaitan dengan profesionalitas guru. Profesionalitas seorang guru pendidikan jasmani olahraga dan kesehatan sangat mempengaruhi proses pembelajaran, harapannya bila guru profesional tujuan dari pendidikan nasional yang salah satunya menjadikan peserta didik sehat, melalui aktivitas gerak bisa tercapai. Asim (2001) menyatakan bahwa kebugaran jasmani adalah aspek fisik dari kebugaran total. Secara definisi kebugaran jasmani diartikan sebagai kemampuan melakukan kegiatan dengan semangat dan berganti-ganti tanpa menimbulkan kelelahan yang berarti dan memiliki sisa energi yang cukup untuk menikmati waktu luang dan menghadapi keadaan darurat. Menurut Wiarto (2015), kebugaran jasmani adalah kesanggupan dan kemampuan tubuh untuk melakukan penyesuaian terhadap pembebasan fisik yang diberikan kepadanya tanpa menimbulkan kelelahan yang berlebihan.

Menurut Nuh (2014), kebugaran jasmani adalah kesanggupan dan kemampuan tubuh melakukan penyesuaian terhadap fisik yang diberikan kepadanya (dari kerja yang dilakukan sehari-hari), tanpa menimbulkan kelelahan yang berarti. Setiap orang membutuhkan kebugaran jasmani yang baik, agar dapat melaksanakan pekerjaannya dengan efektif dan efisien tanpa mengalami kelelahan yang berarti. Sedangkan menurut Widiastuti (2015) kebugaran jasmani adalah kondisi jasmani yang menggambarkan potensi dan kemampuan jasmani untuk melakukan tugas-tugas tertentu dengan hasil yang optimal tanpa memperlihatkan keletihan yang berarti. MENPORA (2008) menjelaskan bahwa kebugaran jasmani merupakan terjemahan dari kata physical fitness yang dapat diartikan sebagai kondisi jasmani yang menggambarkan kemampuan seseorang untuk melakukan suatu pekerjaan tertentu dengan cukup baik.

Berdasarkan beberapa pendapat tersebut, dapat disimpulkan bahwa kebugaran jasmani adalah kemampuan seseorang untuk melakukan suatu aktivitas dalam waktu tertentu tanpa mengalami kelelahan yang berarti dan orang tersebut masih mempunyai cadangan tenaga untuk melakukan aktifitas fisik lainnya. Jadi untuk mencapai kondisi kebugaran jasmani yang prima, seseorang perlu melakukan latihan fisik yang melibatkan komponen kebugaran jasmani dan metode latihan yang benar. Komponen kebugaran jasmani adalah bagian dari kebugaran jasmani yang menjadi satu kesatuan dan tidak dapat dipisahkan satu komponen dengan komponen yang lainnya. Jadi, dengan kata lain, jika kita ingin meningkatkan kebugaran jasmani maka kita harus melatih semua komponen yang ada.Komponen kebugaran jasmani terdiri dari beberapa komponen seperti yang dikemukakan oleh Budiwanto (2015) bahwa komponenkomponen kebugaran jasmani meliputi: (1) daya tahan otot, (2) daya tahan kardiovaskuler, (3) kecepatan, (4) kelincahan, (5) kelenturan, (6) keseimbangan, (7) ketepatan, dan (8) koordinasi. Menurut Asim (2001:12) kebugaran jasmani yang berhubungan dengan kesehatan terdiri dari empat unsur, yaitu: (a) kebugaran kardiovaskuler, (b) kelentukan, (c) kekuatan, dan (d) daya tahan otot.

Komponen-komponen kebugaran jasmani, kebugaran motorik dan kebugaran jasmani yang berkaitan dengan keterampilan motorik meliputi: daya tahan jantung dan paru, kekuatan otot dan daya tahan otot (MENPORA,2008). Widiastuti (2015) membagi beberapa komponen kebugaran jasmani menjadi dua bagian yaitu: "(1) kesegaran jasmani yang berhubungan dengan kesehatan meliputi: (a) daya tahan jantung paru (cardiorespirasi), (b) kekuatan otot, 
(c) daya tahan otot, (d) fleksibilitas, (e) komposisi tubuh, (2) kebugaran jasmani yang berhubungan dengan keterampilan meliputi: (a) kecepatan, (b) power, (c) keseimbangan, (d) kelincahan, (e) koordinasi".

Berdasarkan beberapa pendapat para ahli yang telah dipaparkan dapat disimpulkan bahwa komponen kebugaran jasmani adalah unsur-unsur yang dimiliki oleh jasmani. Komponen-komponen tersebut bersifat saling melengkapi satu sama lain dan untuk meningkatkan kebugaran jasmani, kita harus berlatih sesuai dengan komponen tersebut. Kebugaran jasmani seseorang dapat ditingkatkan jika komponen-komponen kebugaran jasmani dilatih dengan baik dan teratur. Jadi, dengan kata lain kita harus melatih semua komponen kebugaran jasmani tersebut secara teratur.

Penjelasan dari masing-masing komponen kebugaran jasmani tersebut adalah sebagai berikut: Menurut Wiarto (2015), kekuatan otot adalah kontraksi maksimal yang dihasilkan otot, merupakan kemampuan untuk membangkitkan tegangan terhadap suatu tahan. Sedangkan Widiastuti (2015) menjelaskan secara fisiologis kekuatan otot adalah kemampuan otot atau sekelompok otot untuk melakukan satu kali kontraksi secara maksimal melawan tahanan atau beban. Secara fisiologis kekuatan otot adalah kemampuan otot atau sekelompok otot untuk melakukan satu kali kontraksi secara maksimal melawan tahanan atau beban (MENPORA, 2008).

Berdasarkan pendapat ahli dapat disimpulkan bahwa kekuatan merupakan tenaga kontraksi otot dalam melakukan suatu kegiatan maksimal. Kekuatan otot ditentukan oleh sejumlah maksimal tahanan yang dilakukan oleh seseorang untuk mengatasi beban dalam satu kali usaha. Dengan kata lain kekuatan adalah kemampuan untuk melawan beban fisik dari luar maupun dari dalam.

Widiastuti (2015) menyatakan bahwa daya tahan otot merupakan kapasitas otot untuk melakukan kontraksi secara terus menerus pada tingkat intensitas submaksimal. Wiarto (2015:58) berpendapat bahwa daya tahan otot merupakan kapasitas otot untuk melakukan kontraksi submaksimal secara berulang-ulang atau untuk berkontraksi terus menerus dalam waktu tertentu. Sedangkan menurut MENPORA (2008) daya tahan otot adalah kapasitas otot untuk melakukan kontraksi secara terus menerus pada tingkat intensitas submaksimal.

Basith (2012) Kekuatan adalah kemampuan otot untuk mengerahkan kekuatan maksimal dalam waktu yang sangat cepat. Kekuatan sangat penting untuk cabang-cabang olahraga yang memerlukan eksplosif, seperti lari sprint, nomor-nomor lempar dalam atletik, atau cabang-cabang olahraga yang gerakannya didominasi oleh meloncat seperti dalam bola voli, dan juga pada bulutangkis, dan olahraga sejenisnya. Kelentukan juga dapat diartikan sebagai kemampuan seseorang untuk dapat melakukan gerak dengan ruang gerak seluasluasnya dalam persendiannya. Faktor utamanya yaitu bentuk sendi, elastisitas otot, dan ligamen. Chan (2012) Latihan kekuatan harus didasarkan pada persyaratan-persyaratan fisiologis yang spesifik dari cabang olahraga dan harus mampu untuk mengembangkan power dan daya tahan otot. Komi (2003) menyatakan bahwa Gaya maksimal atau torsi otot atau kelompok otot dapat menghasilkan pada kecepatan yang ditentukan.

Yudiana dkk (2012) menyatakan bahwa kontraksi ototyang terjadi pada saat melakukan tahanan atau latihan kekuatan terbagi dalam tiga kategori, yaitu (1) kontraksi isometrik, (2) kontraksi isotonik, dan (3) kontraksi isokinetik. 
Kontraksi isometrik (kontraksi statik) yaitu kontraksi sekelompok otot untuk mengangkat atau mendorong beban yang tidak bergerak dengan tanpa gerakan anggota tubuh, dan panjang otot tidak berubah. Seperti mengangkat, mendorong, atau menarik suatu benda yang tidak dapat digerakan (tembok, pohon, dsb), (2) Kontraksi isotonik (kontraksi dinamik) yaitu kontraksi sekelompok otot yang bergerak dengan cara memanjang dan memendek, atau memendek jika tensi dikembangkan. Latihan kontraksi isotonik dapat dilakukan melalui latihan beban dalam yaitu beban tubuh sendiri, maupun melalui beban luar seperti mengangkat barbel atau menggunakan sejenis alat/mesin latihan kekuatan, dan sejenis lainnya.

Berdasarkan pendapat ahli dapat disimpulkan bahwa daya tahan otot merupakan kemampuan seseorang dalam melakukan kegiatan dalam waktu yang cukup lama yang melibatkan otot atau sekelompok otot.

Daya ledak otot adalah kemampuan otot atau sekelompok otot untuk melakukan kerja secara eksplosif. Daya ledak otot dapat digunakan di saat memerlukan kekuatan otot yang mendadak (Raharjo, 2015). Sedangkan menurut Widiastuti (2015), daya eksplosif adalah gabungan antara kekuatan dan kecepatan atau pengerahan gaya otot maksimum dengan dengan kecepatan maksimum. Utari (2007) berpendapat bahwa daya tahan otot merupakan kemampuan otot untuk melakukan kerja yang berulang-ulang atau terus menerus dengan beban maksimal.Perkembangan kekuatan otot dan daya tahan otot pada dasarnya ditentukan oleh ukuran otot.

Berdasarkan uraian tersebut, dapat disimpulkan bahwa daya ledak adalah kemampuan otot untuk memunculkan kekuatan yang maksimal dalam waktu yang cepat dan dapat digunakan disaat mendadak.

Menurut Wiarto (2015), kecepatan adalah kemampuan untuk menempuh jarak tertentu dalam waktu yang seminimal mungkin. Sedangkan menurut Widiastuti (2015), kecepatan adalah kemampuan untuk berpindah dari satu tempat ke tempat yang lain dalam waktu yang sesingkat singkatnya. MENPORA (2008) kecepatan adalah kemampuan berpindah dari satu tempat ke tempat yang lain dalam waktu yang sesingkat-singkatnya. Sukadiyanto (2011) menyatakan bahwa kecepatan merupakan kemampuan otot atau sekelompok otot untuk menjawab rangsang dalam waktu secepat (sesingkat) mungkin. Kecepatan sebagai hasil perpaduan dari panjang ayunan tungkai dan jumlah langkah. Menurut Sajoto (1988),"kecepatan adalah kemampuan untuk menempuh jarak tertentu, terutama jarak pendek, dalam waktu sesingkat-singkatnya". Amiq (2014) menyatakan bahwa kecepatan adalah kemampuan seseorang untuk mengerjakan gerakan berkesinambungan dalam bentuk yang sama dalam waktu yang sesingkat-singkatnya seperti dalam lari cepat, pukulan dalam tinju, balap sepeda, panahan, dan lain-lain.

Berdasarkan uraian dari beberapa ahli, dapat disimpulkan bahwa kecepatan adalah kemampuan untuk melakukan gerak berpindah dari satu tempat ke tempat lainnya secara cepat dengan jarak tempuh yang dapat diukur dalam waktu yang sesingkat mungkin.

Menurut Budiwanto (2012), "kelentukan adalah luas daerah gerak pada suatu sendi, dengan kata lain kelentukan adalah kemampuan untuk dapat menggerakkan bagian atau anggota badan dengan luas gerak tertentu pada suatu sendi". Kelentukan ditentukan oleh beberapa faktor, terutama adalah jaringan ikat didalam dan sekitar sendi atau otot yaitu 
ligamentum, tendo, bungkus sendi dan bentuk sendi. Fleksibilitas adalah kemampuan sendi untuk melakukan gerakan dalam ruang gerak sendi secara maksimal. Fleksibilitas menunjukkan besarnya pergerakan sendi secara maksimal sesuai dengan kemungkinan gerakan (MENPORA, 2008). Ishak (2012) berpendapat bahwa orang yang mempunyai kelentukan baik adalah orang yang mempunyai ruang gerak yang luas dalam pergerakan sendisendinya dan mempunyai otot-otot yang elastis. Persendian dapat bergerak secara luwes karena adanya kelentukan. Pada permainan bulutangkis, gerakan-gerakan lengan untuk memukul bola memerlukan kelentukan. Apabila kelentukan pada pergelangan tangan kurang baik, memungkinkan pukulan-pukulan yang dilakukan menjadi kaku atau kurang luwes sehingga gerakan yang dilakukan sedikit terhalang ruang geraknya. Yudiana dkk (2012) mengemukakan bahwa kelentukan adalah kemampuan seseorang untuk dapat melakukan gerak dengan ruang gerak seluas-luasnya dalam persendiannya. Faktor utamanya yaitu bentuk sendi.

Berdasarkan beberapa pendapat ahli, dapat disimpulkan bahwa fleksibilitas atau kelentukan merupakan suatu kemampuan sendi untuk bergerak agar semua anggota badan dapat bergerak secara maksimal.

Kelincahan adalah hasil dari kombinasi pembentukan unsur kecepatan, kekuatan dan keseimbangan (Budiwanto, 2012). MENPORA (2008) menyatakan bahwa kelincahan adalah kemampuan untuk mengubah arah atau posisi tubuh dengan cepat yang dilakukan dengan gerakan lainnya. Holmberg (2009) menyatakan bahwa agility termasuk berlari dalam garis lurus dan / atau perubahan arah yang disengaja dengan cepat. kelincahan didefinisikan sebagai keterampilan fisik yang memungkinkan individu untuk secara cepat dan efisien mengurangi kecepatan, mengubah arah, dan mempercepat dalam upaya untuk bereaksi secara tepat terhadap isyarat yang relevan dengan tugas.

Berdasarkan beberapa pendapat ahli, dapat disimpulkan bahwa kelincahan adalah kemampuan mengubah arah tubuh atau bagian tubuh secara cepat tanpa mengalami gangguan pada keseimbangan sehingga seseorang dapat mengubah arah secara cepat sesuai dengan situasi yang dikehendaki.

Koordinasi adalah kemampuan kerjasama beberapa otot untuk menghasilkan gerakan tertentu (Budiwanto, 2012). Koordinasi merupakan kemampuan untuk melakukan gerakan atau kerja dengan cepat dan efisien. Koordinasi merupakan hubungan harmonis sebagai faktor yang terjadi pada suatu gerakan (MENPORA, 2008).

Berdasarkan pendapat tersebut, dapat disimpulkan bahwa koordinasi adalah kemampuan seseorang dalam menggabungkan gerakan yang berbeda ke dalam satu bentuk gerakan yang tepat dan efektif.

Mekadayanti (2015) Keseimbangan adalah kemampuan untuk mempertahankan keseimbangan tubuh ketika ditempatkan di berbagai posisi. Keseimbangan dicapai ketika pusat gravitasi dapat dicapai. Ada dua jenis keseimbangan: 1. keseimbangan statis - melibatkan mempertahankan bentuk yang diinginkan dalam posisi stasioner (misalnya handstand di senam); dan 2. keseimbangan dinamis melibatkan kontrol tubuh ketika bergerak di ruang bebas. Semua gerakan membutuhkan semacam keseimbangan statis, dari mana semua gerakan yang dikendalikan berasal dan dikelola melalui postur efektif dan kontraksi otot dan relaksasi. Untuk mempertahankan keseimbangan saat tidak bergerak atau bergerak bisa dilakukan 
gerakan-gerakan yang bisa mempertahankan keseimbangan (Corbin, 2008). MENPORA (2008) menyatakan bahwa kelincahan adalah kemampuan mempertahankan sikap dan posisi tubuh secara cepat pada saat berdiri (static balance) atau pada saat melakukan gerakan (dynamic balance).

Willardson (2007) mengemukakan bahwa keseimbangan adalah spesifik untuk setiap keterampilan dan ditingkatkan melalui pengulangan postur statis atau gerakan dinamis. Masukan sensorik (penglihatan, sistem vestibular, proprioception) yang diproses di korteks serebral memungkinkan perbaikan keseimbangan terjadi melalui perbaikan dalam pemrograman saraf. Yudiana (2012) menyatakan ada dua macam keseimbangan: 1) Keseimbangan statis adalah mempertahankan sikap pada posisi diam di tempat. Ruang geraknya biasanya sangat kecil, seperti berdiri di atas alas yang sempit. 2) Keseimbangan dinamis adalah kemampuan seseorang untuk mempertahankan posisi tubuhnya pada waktu bergerak. Seperti Sepatu roda, ski air, dan olahraga sejenisnya. Latihan keseimbangan dapat dianggap sebagai jenis pelatihan stabilitas inti karena latihan ini mengaktifkan otot-otot inti.

Berdasarkan pendapat tersebut, dapat disimpulkan bahwa keseimbangan adalah kemampuan seseorang untuk mempertahankan sikap tubuh selama melakukan gerakan dalam bentuk apapun.

Secara pasti tingkat kebugaran jasmani hanya dapat dilakukan melalui tes dan pengukuran yang dilakukan setiap orang. Bentuk tes dan pengukuran kebugaran jasmani bermacam-macam baik cara maupun jenis keterampilan yang diteskan. Tes dan pengukuran kebugaran jasmani seseorang harus memperhatikan tingkat fisiologis dan penurunan fungsi tubuh. Tes dan pengukuran kebugaran jasmani juga harus dapat mengevaluasi status kesehatan, laju penambahan umur, dan tidak boleh menyebabkan cedera. Winarno (2006) berpendapat bahwa tes adalah instrumen atau alat yang berfungsi untuk mengumpulkan data yang berupa pengetahuan maupun keterampilan yang dimiliki oleh siswa maupun mahasiswa, sedangkan pengukuran merupakan bagian dari evaluasi yang menggunakan alat atau teknik tertentu untuk mengumpulkan informasi secara tepat dan benar. Banyak instrumen tes yang digunakan untuk mengukur tingkat kebugaran jasmani seseorang diantaranya adalah: (1) tes multistage,(2) hardvard step up tes, (3) tes lari 12 menit, (4) tes lari 2,4 kilometer, (5) tes kebugaran jasmani versi Asian committee on the Standardization of a physical Fitness Tes (ACSPFT), (6) Tes Kebugaran Jasmani Indonesia (TKJI) untuk remaja umur 13-15 tahun.

Tes Kesegaran Jasmani Indonesia (TKJI) untuk umur 13-15 tahun adalah tolok ukur tes kebugaran jasmani berbentuk rangkaian butir-butir tes yang masuk dalam rangkaian merupakan satu tolok ukur. Sesuai dengan tolok ukur tes kebugaran jasmani, maka tolok ukur ini hanya berlaku untuk mengukur kebugaran jasmani umur 13-15 tahun. Dengan demikian tolok ukur ini dapat berlaku atau tidak dapat dipergunakan untuk mengukur kebugaran jasmani mereka yang tidak termasuk kelompok umur tersebut, maka klasifikasinya hanya berlaku untuk umur 13-15 tahun. Di dalam tes kebugaran jasmani Indonesia untuk umur 1315 tahun terdapat butir-butir tes diantaranya adalah: 1) tes lari 50 meter, 2) pull-up 60 detik, 3) sit-up 60 detik, 4) loncat tegak (vertical jump), 5) lari 1000 meter. Tes tersebut harus dilaksanakan dalam satu satuan waktu tanpa terputus dan tidak dapat dilaksanakan secara bertahap.

Dari berbagai macam parameter tes kebugaran jasmani tersebut, maka dalam penelitian ini, testi diukur tingkat kebugaran jasmani menggunakan TKJI untuk umur 13-15 tahun yang 
dikeluarkan oleh Pusat Kebugaran Jasmani dan Rekreasi Departemen Pendidikan dan Kebudayaan Jakarta pada tahun 2010. TKJI ini memerlukan banyak tenaga, oleh karena itu peserta tes harus dalam keadaan sehat dan siap untuk melaksanakan tes. Hendaknya para peserta tes mengerti dan memahami cara pelaksanaan tes, diharapkan peserta melakukan pemanasan (warming up) terlebih dahulu sebelum melakukan tes. Jika para peserta tes tidak dapat melaksanakan satu jenis tes atau lebih dinyatakan gagal atau tidak mendapatkan nilai. Dari kelima macam tes kebugaran jasmani diatas, peneliti menggunakan Tes Kesegaran Jasmani Indonesia karena setiap butir tes yang terdapat pada TKJI sudah dapat mengukur sebagian besar komponen kebugaran jasmani. Selain itu TKJI sudah distandarkan dengan keadaan kondisi siswa yang ada di Indonesia, berbeda dengan multistage fitness test (MFT) yang standartnya adalah ruang lingkup Internasional dan hanya mengukur daya tahan saja, hal tersebut juga terdapat pada tes hardvard step up, tes lari 12 menit, tes lari 2,4 km yang hanya mengukur daya tahan saja, tes yang didalam butir tesnya hampir mirip dengan TKJI terdapat pada tes kebugaran jasmani versi ACSPFT, hanya saja standar tesnya dalam ruang lingkup Asia. Dengan mempertimbangkan alasan tersebut maka peneliti memilih menggunakan tes TKJI untuk mengukur tingkat kebugaran jasmani siswa SMP Insan Terpadu Pakis Kabupaten Malang.

\section{Metode}

Dalam penelitian ini peneliti menggunakan rancangan penelitian survei. Ditinjau dari tujuan rancangan penelitian, maka penelitian ini termasuk dalam penelitian deskriptif, yaitu sebuah metode yang efektif untuk tujuan mendeskripsikan atau menggambarkan fenomenafenomena yang ada, baik fenomena yang bersifat alamiah maupun fenomena yang bersifat rekayasa. Singarimbun dan Effendi (1991) menyatakan bahwa "penelitian deskriptif dimaksudkan untuk pengukuran yang cermat terhadap fenomena sosial tertentu, peneliti mengembangkan konsep dan menghimpun fakta, tetapi tidak melakukan pengujian hipotesa". Sedangkan menurut Winarno (2013), penelitian deskriptif bertujuan untuk mendeskripsikan (memaparkan) peristiwa yang terjadi pada masa kini. Penelitian deskriptif bertujuan untuk mendeskripsikan atau memaparkan kejadian yang terjadi saat ini secara sistematis, akurat, dan factual tentang sifat-sifat atau faktor-faktor tertentu yang diteliti, jadi penelitian tidak melakukan kendali atau perlakuan tetapi hanya mengumpulkan data berdasarkan fakta yang ada.

Dalam penelitian deskriptif, peneliti tidak melakukan manipulasi atau memberikan perlakuan-perlakuan tertentu terhadap variabel, tetapi semua kegiatan, keadaan, kejadian, aspek komponen dan variabel berjalan apa adanya. Penelitian ini hanya bertujuan untuk mendeskripsikan tentang prediksi tingkat kebugaran jasmani siswa SMP Insan Terpadu Pakis Kabupaten Malang.

Subjek penelitian ini adalah SMP Insan Terpadu Pakis kabupaten Malang. Fokus penelitian adalah tingkat kebugaran jasmani siswa SMP Insan Terpadu Pakis kabupaten Malang dengan keseluruhan jumlah siswa sebanyak 64 siswa.

Instrumen yang digunakan berupa instrument tes yang meliputi tes kebugaran jasmani dalam bentuk Tes Kesegaran Jasmani Indonesia (TKJI) yang merupakan suatu jenis tes yang digunakan untuk mengetahui tingkat kebugaran jasmani seseorang, dalam pelaksanaanya seseorang harus memiliki fisik yang kuat, karena tes tersebut hanya dilakukan satu kali 
pengulangan saja setiap satu butiran tes, butiran-butiran tes tersebut adalah: 1) tes lari 50 meter, 2) pull-up 60 detik, 3) sit-up 60 detik, 4) loncat tegak (vertical jump), 5) lari 1000 meter.

Pertimbangan menggunakan instrument ini karena tes ini valid, menggunakan norma, ekonomis, objektif dan interest yang merupakan syarat memilih kriteria tes kebugaran jasmani. Penilaian kebugaran jasmani bagi remaja yang telah mengikuti tes kebugaran jasmani dinilai dengan menggunakan Tabel Nilai (untuk menilai prestasi dari masing-masing tes) dan menggunkan norma (untuk menentukan klasifikasi/kategori tingkat kebugaran jasmani). Tabel nilai seperti tertera pada Tabel 1 .

Tabel 1. Nilai TKJI (Untuk Putra Usia 13 -15 Tahun)

\begin{tabular}{cccccc}
\hline Nilai & $\begin{array}{c}\text { Lari 50 } \\
\text { meter }\end{array}$ & $\begin{array}{c}\text { Pull-up 60 } \\
\text { detik }\end{array}$ & $\begin{array}{c}\text { Sit-up 60 } \\
\text { detik }\end{array}$ & $\begin{array}{c}\text { Loncat } \\
\text { tegak }\end{array}$ & $\begin{array}{c}\text { Lari 1000 } \\
\text { meter }\end{array}$ \\
\hline 5 & S.d $-6,7^{\prime \prime}$ & $16-$ Keatas & $38-$ Keatas & 66 Keatas & S.d - 3'04" \\
4 & $6.8^{\prime \prime}-7,6^{\prime \prime}$ & $11-15$ & $28-37$ & $53-65$ & $3^{\prime} 05^{\prime \prime}-3^{\prime} 53^{\prime \prime}$ \\
3 & $7,7^{\prime \prime}-8,7^{\prime \prime}$ & $6-10$ & $19-27$ & $42-52$ & $3^{\prime} 54^{\prime \prime}-4^{\prime} 46^{\prime \prime}$ \\
2 & $8,8^{\prime \prime}-10,3^{\prime \prime}$ & $2-5$ & $8-18$ & $31-41$ & $4^{\prime} 47^{\prime \prime}-6^{\prime} 04^{\prime \prime}$ \\
1 & $10,4^{\prime \prime}-$ dst & $0-1$ & $0-7$ & $0-30$ & $6^{\prime} 05^{\prime \prime}-$ dst 1 \\
\hline
\end{tabular}

Untuk mengklasifikasi tingkat kebugaran jasmani siswa, yang telah mengikuti TKJI dipergunakan norma seperti tertera pada Tabel 2 untuk putra.

Tabel 2. Norma TKJI Usia 13-15 Tahun (Untuk Putra)

\begin{tabular}{ccc}
\hline Nilai & Jumlah Nilai & Klasifikasi \\
\hline 5 & $22-25$ & Baik Sekali (BS) \\
4 & $18-21$ & Baik (B) \\
3 & $14-17$ & Sedang (S) \\
2 & $10-13$ & Kurang (K) \\
1 & $5-9$ & Kurang Sekali (KS) \\
\hline
\end{tabular}

Teknik pengumpulan data yang digunakan dalam penelitian ini adalah teknik tes dan pengukuran dilengkapi dengan petunjuk pelaksanaan tes. Data yang diperoleh dari masingmasing siswa merupakan data kasar, kemudian diubah menjadi nilai dan selanjutnya diolah kedalam tabel tes kebugaran jasmani untuk putra. Metode yang digunakan adalah survei dengan teknik pengumpulan data tes dan pengukuran. Tahap dalam pengumpulan data meliputi, (1) tahap persiapan, (2) tahap pelaksanaan, (3) tahap pelaporan. Masing-masing tahap pengumpulan data tersebut dijelaskan seperti berikut:

Tahap persiapan yang dilakukan agar proses pengumpulan data lancar, maka akan dilakukan hal sebagai berikut: Studi kepustakaan (mencari literature atau buku), (b) Survei siswa dan menghubungi guru untuk melaksanakan tes, (c) Petunjuk teknis pelaksanaan tes TKJI, (d) Menyiapkan peralatan dan fasilitas yang digunakan untuk tes, (e) Petunjuk teknis pelaksanaan tes TKJI, (f) Menyiapkan peralatan dan fasilitas yang digunakan untuk tes.

Mengurus surat izin penelitian kepada kepala sekolah SMP Insan Terpadu Pakis Kabupaten Malang. 
Prosedur pelaksanaan tes adalah sebagai berikut: Absensi kelengkapan siswa, (b) Sebelum melakukan tes keseluruhan siswa melakukan pemanasan, (c) Alat yang dibutuhkan yaitu, stopwatch, lembar pencatat hasil, (d) Melakukan tes TKJI, (e) Mencatat hasil tes TKJI.

Setelah seluruh tes dilakukan oleh siswa didik, maka hasil yang didapatkan diolah kedalam tabel nilai hasil tes TKJI.

Analisis data merupakan suatu langkah yang penting dalam penelitian. Data yang sudah terkumpul tidak berarti apa-apa jika tidak diolah, karena itu perlu analisis data tersebut. Analisis data adalah kegiatan mengubah data hasil penelitian menjadi informasi yang dapat digunakan untuk mengambil kesimpulan dalam suatu penelitian.

Berdasarkan pada tujuan penelitian untuk mengetahui bagaimana tingkat kebugaran jasmani siswa SMP Insan Terpadu Pakis kabupaten Malang, maka teknik analisis data yang digunakan berupa teknik statistika deskriptif kuantitatif dalam bentuk distribusi frekuensi relatif dan grafik, karena dalam penelitian ini fokusnya pada survei tingkat kebugaran jasmani, maka data yang terkumpul dari masing-masing tes di konversi kedalam nilai yang berskala 14 dan selanjutnya di jumlahkan untuk di konversi kedalam tabel norma tingkat kebugaran jasmani. Tabel 3 di bawah ini menyajikan klasifikasi atau kategori tingkat kebugaran jasmani dari seluruh rangkaian butiran tes kebugaran jasmani.

Tabel 3. Norma Tes Kesegaran Jasmani

\begin{tabular}{ccc}
\hline Nilai & Jumlah Nilai & Klasifikasi \\
\hline 5 & $22-25$ & Baik Sekali (BS) \\
4 & $18-21$ & Baik (B) \\
3 & $14-17$ & Sedang (S) \\
2 & $10-13$ & Kurang (K) \\
1 & $5-9$ & Kurang Sekali (KS) \\
\hline
\end{tabular}

\section{Hasil dan Pembahasan}

\subsection{Hasil}

Tujuan penelitian ini adalah untuk mengetahui tingkat kebugaran jasmani siswa SMP Insan Terpadu Pakis Kabupaten Malang, yang berjumlah 64 siwa. Penelitian ini menggunakan tes dan pengukuran terhadap 5 tes komponen fisik yang terdapat pada tingkat kebugaran jasmani Indonesia untuk remaja usia 13-15 tahun, yang bertujuan untuk menunjang kemampuan fisik bagi siswa SMP Insan Terpadu Pakis Kabupaten Malang.

Penelitian tingkat kebugaran jasmani siswa SMP Insan Terpadu Pakis Kabupaten Malang menggunakan tes TKJI usia 13-15 tahun. Jenis-jenis butiran tes TKJI meliputi: (1) lari 50 meter, (2) gantung angkat tubuh (pull-up) , (3) baring duduk (sit-up) 60 detik, (4) loncat tegak (vertical jump), (5) lari 1000 meter.

Sesuai dengan pengertian kebugaran jasmani yaitu kesanggupan tubuh seseorang untuk menjalani aktivitas sehari-hari tanpa mengalami rasa lelah yang berlebihan, jadi untuk mengetahui tingkat kebugaran jasmani seseorang dapat dilakukan dengan tes kebugaran jasmani menggunakan TKJI usia 13-15 tahun. Dalam pelaksanaan tes TKJI pada siswa SMP Insan Terpadu Pakis Kabupaten Malang dilakukan pada waktu dan tempat yang sama yaitu 
pada hari Kamis, tanggal 24 Oktober 2019 pukul 07.00-12.00 WIB, di SMP Insan Terpadu Pakis Kabupaten Malang, dengan jumlah 64 siswa. Tes dilakukan sesuai urutan tes dan dilakukan secara bergantian, yaitu diawali dengan tes lari 50 meter dilanjutkan dengan tes gantung angkat tubuh (pull-up) 60 detik, kemudian tes baring duduk (sit-up) 60 detik, kemudian tes loncat tegak (vertical jump) dan terakhir tes 1000 meter. Tes ini bertujuan untuk mengetahui tingkat kebugaran jasmani siswa SMP Insan Terpadu Pakis Kabupaten Malang.

Proses pengambilan data tingkat kebugaran jasmani pada siswa SMP Insan Terpadu Pakis Kabupaten Malang yang diselenggarakan pada hari Kamis tanggal 24 Oktober 2019 pukul 07.00-12-00 WIB yang bertempat di SMP Insan Terpadu Pakis Kabupaten Malang, dengan rincian jumlah 64 siswa.

Untuk dapat melihat tingkat kebugaran jasmani siswa dari hasil penelitian, didapatkan hasil skor tertinggi yakni 5 (baik sekali) dan skor terendah yakni nilai 1 (kurang sekali) pada setiap butir tes. Hasil yang diperoleh dalam pelaksanaan penelitian dalam menganalisis data diolah menggunakan analisis deskriptif persentase. Tes tersebut terdiri dari: (1) tes lari 50 meter, (2) tes gantung angkat tubuh (pull-up) 60 detik, (3) tes baring duduk (sit-up) 60 detik, (4) tes loncat tegak (vertical jump), (5) tes lari 1000 meter untuk kelompok usia 13-15 tahun. Setelah diperoleh data hasil tes maka data tersebut diklasifikasikan sesuai dengan norma klasifikasi TKJI. Penilaian kebugaran jasmani bagi remaja yang telah mengikuti tes kebugaran jasmani dinilai dengan menggunakan Tabel Nilai (untuk menilai prestasi dari masing-masing tes) dan menggunakan norma (untuk menentukan klasifikasi/kategori tingkat kebugaran jasmani). Tabel nilai seperti tertera pada Tabel 4

Tabel 4. Nilai tes TKJI (Untuk Usia 13 -15 Tahun)

\begin{tabular}{cccccc}
\hline Nilai & $\begin{array}{c}\text { Lari 50 } \\
\text { meter }\end{array}$ & $\begin{array}{c}\text { Pull-up 60 } \\
\text { detik }\end{array}$ & $\begin{array}{c}\text { Sit-up 60 } \\
\text { detik }\end{array}$ & $\begin{array}{c}\text { Loncat } \\
\text { tegak }\end{array}$ & $\begin{array}{c}\text { Lari 1000 } \\
\text { meter }\end{array}$ \\
\hline 5 & S.d $-6,7^{\prime \prime}$ & $16-$ Keatas & $38-$ Keatas & 66 Keatas & S.d - 3'04" \\
4 & $6.8^{\prime \prime}-7,6^{\prime \prime}$ & $11-15$ & $28-37$ & $53-65$ & $3^{\prime} 05^{\prime \prime}-3^{\prime} 53^{\prime \prime}$ \\
3 & $7,7^{\prime \prime}-8,7^{\prime \prime}$ & $6-10$ & $19-27$ & $42-52$ & $3^{\prime} 54^{\prime \prime}-4^{\prime} 46^{\prime \prime}$ \\
2 & $8,8^{\prime \prime}-10,3^{\prime \prime}$ & $2-5$ & $8-18$ & $31-41$ & $4^{\prime} 47^{\prime \prime}-6^{\prime} 04^{\prime \prime}$ \\
1 & $10,4^{\prime \prime}-\mathrm{dst}$ & $0-1$ & $0-7$ & $0-30$ & $6^{\prime} 05^{\prime \prime}-$ dst 1 \\
\hline
\end{tabular}

Untuk mengklasifikasi tingkat kebugaran jasmani siswa, yang telah mengikuti tes TKJI dipergunakan norma seperti tertera pada Tabel 5 .

Tabel 5. Norma Tes Kesegaran Jasmani

\begin{tabular}{ccc}
\hline Nilai & Jumlah Nilai & Klasifikasi \\
\hline 5 & $22-25$ & Baik Sekali (BS) \\
4 & $18-21$ & Baik (B) \\
3 & $14-17$ & Sedang (S) \\
2 & $10-13$ & Kurang (K) \\
1 & $5-9$ & Kurang Sekali (KS) \\
\hline
\end{tabular}

Berikut ini adalah data hasil tes kebugaran jasmani siswa SMP Insan Terpadu Pakis Kabupaten Malang. Uraian data hasil tes dapat dilihat pada tabel 6 berikut. 
Tabel 6. Hasil Tingkat Kebugaran Jasmani siswa SMP Insan Terpadu Pakis Kabupaten Malang

\begin{tabular}{ccccc}
\hline No. & Nilai & Kategori & Jumlah Peserta & $\mathbf{\%}$ \\
\hline 1 & 5 & Baik Sekali & - & - \\
2 & 4 & Baik & 29 & $45,31 \%$ \\
3 & 3 & Sedang & 35 & $54,69 \%$ \\
4 & 2 & Kurang & - & - \\
5 & 1 & Kurang Sekali & - & - \\
\hline
\end{tabular}

Berdasarkan tabel 6 dapat diketahui bahwa hasil tes kebugaran jasmani siswa SMP Insan Terpadu Pakis Kabupaten Malang yang berjumlah 64 siswa dapat diketahui bahwa tidak ada siswa yang termasuk dalam klasifikasi baik sekali, kurang dan kurang sekali, terdapat 29 $(45,31 \%)$ siswa dengan kategori baik dan 35 (54,69\%) siswa dengan kategori sedang.

Poligon untuk tingkat kebugaran jasmani siswa SMP Insan Terapadu Pakis Kabupaten Malang dapat dilihat pada gambar 6.

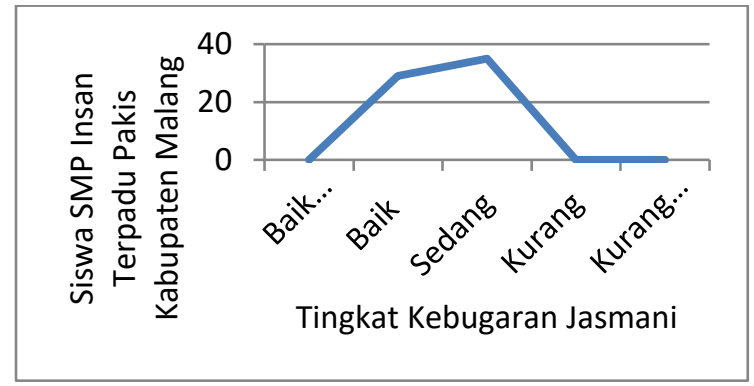

\section{Gambar 1. Poligon Tingkat Kebugaran Jasmani siswa SMP Insan Terpadu Pakis Kabupaten Malang}

Jadi dapat disimpulkan bahwa tingkat kebugaran jasmani siswa SMP Insan Terpadu Pakis Kabupaten Malang termasuk dalam kategori sedang.

Tingkat kebugaran jasmani yang baik sangatlah penting untuk dimiliki setiap siswa, tidak terkecuali untuk seluruh siswa SMP Insan Terpadu Pakis Kabupaten Malang. Budiwanto (2015) bahwa komponen-komponen kebugaran jasmani meliputi: (1) daya tahan otot, (2) daya tahan kardiovaskuler, (3) kecepatan, (4) kelincahan, (5) kelenturan, (6) keseimbangan, (7) ketepatan, dan (8) koordinasi. Menurut Asim (2001:12) kebugaran jasmani yang berhubungan dengan kesehatan terdiri dari empat unsur, yaitu: (a) kebugaran kardiovaskuler, (b) kelentukan, (c) kekuatan, dan (d) daya tahan otot.

Komponen-komponen kebugaran jasmani, kebugaran motorik dan kebugaran jasmani yang berkaitan dengan keterampilan motorik meliputi: daya tahan jantung dan paru, kekuatan otot dan daya tahan otot (MENPORA, 2008). Untuk mengetahui tingkat kebugaran jasmani siswa SMP Insan Terpadu Pakis Kabupaten Malang, maka peneliti melakukan tes kebugaran jasmani kepada seluruh siswa SMP Insan Terpadu Pakis Kabupaten Malang. Penilaian kebugaran jasmani bisa menggunakan beberapa tes kebugaran, salah satu diantaranya adalah menggunakan Tes Kebugaran Jasmani Indonesia (TKJI) yang digunakan oleh peneliti. Tes yang dilakukan meliputi: 1) tes lari 50 meter, 2) tes gantung angkat tubuh (pull;up) 60 detik, 3) tes baring duduk (sit-up) 60 detik, 4) tes loncat tegak (vertical jump), dan 5) tes lari 1000 meter. 
Dari hasil penelitian yang telah dilakukan oleh Puspitasari (2017), diperoleh nilai maksimal sebesar 107,66 dan nilai minimal sebesar 7,70. Mean sebesar 51,53. Median sebesar 48,88. Modus sebesar 43,78. Standar deviasi sebesar 18,85 dan varian sebesar 355,32. Sedangkan dari hasil keseluruhan tingkat kebugaran jasmani siswa SMP Negeri 2 Sendang, Kabupaten Tulungagung menunjukkan kategori baik 20\%, cukup 69\% dan kurang $11 \%$. Sehingga dari data tersebut tingkat kebugaran jasmani siswa SMP Negeri 2 Sendang, Kabupaten Tulungagung termasuk dalam kategori cukup.

Berdasarkan hasil penelitian dari Ginting (2012), uji analisis dan pembahasan hasil penelitian maka dapat disimpulkan sebagai berikut:

Siswa SMP Negeri 1 Kabanjahe Tahun Ajaran 2011/2012 memiliki tingkat kebugaran jasmani kurang. 2) Siswa SMP Negeri 1 Kabanjahe secara umum memiliki Indeks Massa Tubuh pada kategori normal, yaitu pada -2SD sampai 2SD. 3) Siswa obesitas memiliki tingkat kebugaran jasmani yang lebih rendah dibandingkan dengan siswa kurus, normal, dan gemuk. 4) Terdapat korelasi negatif antara Indeks Massa Tubuh dengan tingkat kebugaran jasmani pada siswa SMP Negeri 1 Kabanjahe tahun ajaran 2011/2012. 5) Semakin tinggi Indeks Massa Tubuh, semakin rendah tingkat kebugaran jasmani. 6) Nilai Indeks Massa Tubuh harus diimbangi dengan aktivitas fisik yang teratur.

Berdasarkan paparan data di atas dapat ditemukan beberapa temuan penelitian sebagai berikut.

Berdasarkan hasil penelitian tingkat kebugaran jasmani siswa SMP Insan Terpadu Pakis Kabupaten Malang dengan jumlah 35 siswa termasuk dalam kategori sedang, ada 29 siswa termasuk dalam kategori baik. Tidak terdapat siswa dalam kategori sangat baik, kurang dan kurang sekali.

Wiarto (2015) menjelaskan bahwa kebugaran jasmani adalah kesanggupan dan kemampuan tubuh untuk melakukan penyesuaian (adaptasi) terhadap pembebasan fisik yang diberikan kepadanya tanpa menimbulkan kelelahan yang berlebihan. Komponen kebugaran jasmani adalah bagian dari kebugaran jasmani yang menjadi satu kesatuan dan tidak dapat dipisahkan satu komponen dengan komponen yang lainnya. Jadi, dengan kata lain, jika kita ingin meningkatkan kebugaran jasmani maka kita harus melatih semua komponen yang ada.Menurut Widiastuti (2015), kebugaran jasmani adalah kondisi jasmani yang menggambarkan potensi dan kemampuan jasmani untuk melakukan tugas tugas tertentu dengan hasil yang optimal tanpa memperlihatkan keletihan yang berarti.

Komponen kebugaran jasmani terdiri dari beberapa komponen seperti yang dikemukakan oleh Budiwanto (2015) bahwa komponen-komponen kebugaran jasmani meliputi: (1) daya tahan otot, (2) daya tahan kardiovaskuler, (3) kecepatan, (4) kelincahan, (5) kelenturan, (6) keseimbangan, (7) ketepatan, dan (8) koordinasi. Menurut Asim (2001:12) kebugaran jasmani yang berhubungan dengan kesehatan terdiri dari empat unsur, yaitu: (a) kebugaran kardiovaskuler, (b) kelentukan, (c) kekuatan, dan (d) daya tahan otot.

Pengukuran tingkat kebugaran jasmani dalam penelitian ini terdiri dari macam-macam tes yaitu (a) tes lari 50 meter, (b) tes gantung angkat tubuh (pull-up) 60 detik, (c) tes baring duduk (sit-up) 60 detik, (d) tes loncat tegak(vertical jump), dan (e) tes lari 1000 meter. 
Berdasarkan hasil penelitian ditemukan bahwa untuk tes lari 50 meter dari 64 siswa terdapat 3 siswa termasuk kategori baik sekali, 11 siswa termasuk kategori baik, 38 siswa termasuk kategori sedang, 12 siswa termasuk kategori kurang, dan tidak ada siswa termasuk kategori kurang sekali. Tes gantung angkat tubuh tidak terdapat siswa kategori baik sekali dan baik, 29 siswa termasuk kategori sedang, 35 siswa termasuk kategori kurang, dan tidak ada siswa termasuk kategori kurang sekali. Tes baring duduk terdapat 16 siswa termasuk kategori baik sekali, 48 siswa termasuk kategori baik, dan tidak terdapat siswa dalam kategori sedang, kurang dan kurang sekali. Tes loncat tegak tidak terdapat siswa dalam kategori baik sekali, 15 siswa termasuk kategori baik, 45 siswa termasuk kategori sedang, 4 siswa termasuk kategori kurang, dan tidak ada siswa termasuk kategori kurang sekali. Pada kategori tes terakhir yaitu tes lari 1000 meter tidak terdapat siswa dalam kategori baik sekali, 36 siswa termasuk kategori baik, 28 siswa termasuk kategori sedang, dan tidak ada siswa yang termasuk kategori kurang dan kurang sekali. Berdasarkan temuan penelitian tersebut di atas dapat disimpulkan bahwa tingkat kebugaran jasmani berdasarkan kategori tes siswa SMP Insan Terpadu Pakis Kabupaten Malang Termasuk dalam kategori sedang.

\subsection{Pembahasan}

Dari hasil yang dipaparkan tersebut, dapat dilihat pada Tabel 2 mengenai kriteria persentase ketuntasan yang mana dijelaskan bahwa jika melebihi 70\% masuk dalam kategori cukup dan dapat digunakan. Sementara hasil yang telah didapat peneliti mendapatkan hasil dari observer 1 sebanyak 82,22\% dan observer 2 sebanyak 84,44\% masuk dalam kategori baik hingga sangat baik. Sehingga dapat disimpulkan bahwa dengan menggunakan metode latihan variasi dapat meningkatkan teknik pukulan forehand dropshot bagi atlet usia 8-12 tahun di klub PB. Sari Agung Genteng Kabupaten Banyuwangi.

Peneliti mengkaji dari penelitian sebelumnya dengan penggunaan metode latihan variasi dapat meningkatkan teknik pukulan forehand dropshot bulutangkis, dijelaskan oleh Mahmuda Permata Sari (2018) bahwa "dengan menggunakan metode latihan variasi dapat meningkatkan teknik pukulan forehand dropshot bulutangkis pada atlet usia 8-12 tahun di PB. Brawijaya JR".

Penelitian lain oleh Pradana (2016) menjelaskan bahwa dengan menggunakan latihan drilling dan strokes pada pukulan dropshot dapat meningkatkan pukulan dropshot pada atlet usia 10-11 tahun PB Natura Prambanan Yogyakarta.

Penelitian oleh Susanto (2017) menjelaskan bahwa pengembangan model latihan pukulan forehand dropshot dapat meningkatkan keterampilan pukulan forehand dropshot pada siswa ekstrakurikuler di SMP Negeri 2 Trawas dengan hasil ujicoba sebesar 78,7\% dan 80\% dengan kriteria baik.

Penelitian oleh Kusuma (2017) menjelaskan bahwa latihan dropshot dengan menggunakan model latihan rintangan tali 0,5 meter dapat meningkatkan keterampilan pada permainan bulutangkis pada klub PB Bersama Masbagik Lombok Timur.

Penelitian oleh Pardiman, Sugiharto \& Rifai (2018) menjelaskan bahwa latihan exercise dan koordinasi mata dan tangan dapat meningkatkan signifikan akurasi pukulan dropsot di PB C-PLUSco Semarang. 
Penelitian lain juga dilakukan oleh Tong dan Hong (2017) yang menjelaskan bahwa dalam pertandingan pemain dunia single bulutangkis diperoleh data teknik pukulan dropshot menempati urutan kedua teratas yang sering dilakukan dibandingkan dengan teknik lainnya.

Penelitian juga dilakukan oleh El-Gezawi (2015) yang menjelaskan beberapa teknik dapat dilatih menggunakan model-model atau variasi-variasi latihan tertentu salah satunya adalah forehand dropshot. Dalam penelitiannya diterapkan macam-macam latihan yang mengarah ke kemampuan visual dalam pertandingan bulutangkis.

Penelitian yang telah dipaparkan di atas menjadi pendukung dari penelitian yang dilakukan oleh peneliti tentang pukulan forehand dropshot bulutangkis pada atlet usia 8-12 tahun di PB Sari Agung Kabupaten Banyuwangi dengan hasil dari observer 1 sebanyak 82,22\% dan observer 2 sebanyak 84,44\% masuk dalam kategori baik hingga sangat baik.

\section{Simpulan}

Berdasarkan hasil penelitian yang telah dijelaskan pada halaman terdahulu, maka dapat disimpulkan bahwa tingkat kebugaran jasmani siswa SMP Insan Terpadu Pakis Kabupaten Malang dominan termasuk kategori sedang.Berdasarkan hasil penelitian dan temuan yang dihasilkan dalam penelitian ini, maka dapat dikemukakan saran-saran sebagai berikut: (1) Diharapkan setelah mengetahui tingkat kebugaran jasmani siswa dapat dijadikan sebagai tolak ukur dalam meningkatan kebugaran jasmaninya yaitu dengan melakukan aktivitas fisik yang rutin, teratur, sistematis, dan terprogram. (2) Diharapkan setelah mengetahui tingkat kebugaran jasmani siswa SMP Insan Terpadu Pakis Kabupaten Malang, guru dapat menganalisis faktor-faktor yang menjadi penyebab baik dan kurangnya tingkat kebugaran jasmani siswa didiknya dan dapat dijadikan tolak ukur untuk revisi program pembelajaran yang diterapkan dalam pembelajaran, serta diberikan alternatif-alternatif baru untuk merangsang agar siswa rajin dan aktif saat pembelajaran berlangsung sesuai yang telah diprogramkan, agar dapat meraih prestasi yang diharapkan. (3) Diharapkan hasil penelitian ini dapat dijadikan sebagai informasi, rujukan, dan pembanding untuk penelitian selanjutnya khususnya di bidang kebugaran jasmani..

\section{Daftar Rujukan}

Amiq, F. (2014). Futsal (Sejarah, Teknik Dasar, persiapan Fisik, Strategi, dan Peraturan Permainan).

Asim. (2001). Pertumbuhan dan Perkembangan Motorik. Jurusan Ilmu Keolahragaan. Fakultas Ilmu Pendidikan. Universitas Negeri Malang.

Basith, A. (2012). Hubungan Panjang Lengan Dan Kelentukan Dengan Kemampuan Smash Dalam Permainan Bolavoli Pada Siswa Smk Negeri 2 Makassar. COMPETITOR: Jurnal Pendidikan Kepelatihan Olahraga, $4(1)$.

Budiwanto, S. (2012). Metodologi Latihan Olahraga. Malang: Universitas Negeri Malang.

Budiwanto, S. (2015). Metodologi Penelitian dan Penerapannya Dalam Keolahragaan. Malang: UM Press

Chan, F. (2012). Strength Training (Latihan Kekuatan). PORKES FKIP Universitas Jambi.

Corbin, B. C. (2008). Concepts Of Physical Fitness. New York: MC Graw Hill.

Giriwijoyo \& Sidik, (2013). Ilmu Kesehatan Olahrga. Bandung: PT Remaja Rosdakarya.

Holmberg, P. M. (2009). Agility training for experienced athletes: A dynamical systems approach. Strength \& Conditioning Journal, 31(5), 73-78.

Ishak, M. (2012). Kontribusi Daya Ledak Lengan, Kelentukan Pergelangan Tangan dan Kelincahan Kaki Terhadap Pukulan Smash pada Permainan Bulutangkis Pada Siswa SMA Negeri 2 Bantaeng. COMPETITOR: Jurnal Pendidikan Kepelatihan Olahraga, 4(3). 
Kemenpora. (2008). Buku Pedoman Biomekanika dan Kebugaran Jasmani. Jakarta: Pusat Pengembangan Ilmu Pengetahuan dan Teknologi dan Kesehatan Olahraga Nasional.

Komi, P. V. (2003). Strength And Power In Sport.

Kurniawan, R. (2017). Peningkatan Profesionalisme Guru Pendidikan Jasmani Olahraga Dan Kesehatan Dalam Pekembangan Ilmu Pengetahuan Dan Teknologi. In Seminar Nasional Pendidikan Olahraga (Vol. 1, No. 1, pp. 298-307).

Lumpkin, A. (2010). Instruction Physical Education, Exercise Science,And Sport Studies. New York:The McGrawHillCompanies.

Mardiana, A. (2014). Pendidikan jasmani dan olahraga.

Mekadayanti, Indrayani, N. L. K., \& NK, K. D. (2016). Optimalisasi Kelenturan (Flexibelity), Keseimbangan (Balance), dan Kekuatan (Strength) Tubuh Manusia Secara Instan dengan Menggunakan "Secret Method"*. VIRGIN: Jurnal Ilmiah Kesehatan Dan Sains, 1(1). 40-49

Mulyaningsih, F. dkk. (2010). Pendidikan Jasmani, Olahraga dan Kesehatan untuk Kelas IV SD/MI.

Morgan, P. J., \& Hansen, V. (2008). Classroom teachers' perceptions of the impact of barriers to teaching physical education on the quality of physical education programs. Research quarterly for exercise and sport, 79(4), 506-516.

Nuh, M. (2014). Pendidikan Jasmani Olahraga dan Kesehatan SMA/MA/SMK/MAK Kelas X. Jakarta; Kemendikbud.

Nurhasan. (2005). Petunjuk Praktis Pendidikan Jasmani. Surabaya: UNESA University Press

Raharjo, C. S. (2015). Perbedaan tingkat kebugaran jasmani siswa putra smp swasta gedeg dan smp negeri 2 gedeg kelas VIII kecamatan gedeg, kabupaten mojokerto tahun pelajaran 2014/2015. BRAVO'S (Jurnal Prodi Pendidikan Jasmani \& Kesehatan), 3(3).

Sajoto, M. (1988). Pembinaan Kondisi Fisik Dalam Olahraga. Jakarta: Departemen Pendidikan dan Kebudayaan Direktorat Jendral Pendidikan Tinggi Proyek Pengembangan Lembaga Pendidikan Tenaga Kependidikan.

Singarimbun \& Effendi. (1991). Metode Penelitian Survei. Jakarta: Lembaga Penelitian, Pendidikan dan Penerangan Ekonomi dan Sosial.

Sukadiyanto. (2011). Pengantar Teori dan Metodologi Melatih Fisik. Bandung: Lubuk Agung.

Utari, A. (2007). Hubungan indeks massa tubuh dengan tingkat kesegaran jasmani pada anak usia 12-14 tahun. Doctoral dissertation, program Pascasarjana Universitas Diponegoro.

Wiarto. (2015). Panduan Berolahraga untuk Kesehatan dan Kebugaran. Yogyakarta: Graha Ilmu.

Widiastuti. (2015). Tes dan Pengukuran Olahraga. Jakarta: Raja grafindo Persada.

Widijoto, H. (2009). Petunjuk Teknis Praktik Pengalaman Lapangan. Malang: Universitas Negeri Malang.

Willardson, J. M. (2007). Core stability training:applications to sports conditioning programs. Journal of Strength and Conditioning Research, 21(3), 979-985

Winarno, M. E. (2006). Evaluasi Dalam Pendidikan Jasmani dan Olahraga. Jakarta: Center For Human Capacity Development.

Winarno, M. E. (2013). Metode Penelitian dalam Pendidikan Jasmani. Malang: Universitas Negeri Malang.

Yudiana, Y., Subardjah, H., \& Juliantine, T. (2012). Latihan Fisik. 